\title{
Relationship between Anxiety and Burning Mouth Syndrome of Psychiatric Outpatients
}

\author{
Alzeressy Putri \\ Faculty of Dentistry, Universitas Sumatera Utara \\ Medan, Indonesia
}

\author{
Nurdiana, Aida Fadhilla Darwis \\ Department of Oral Medicine \\ Faculty of Dentistry, Universitas Sumatera Utara \\ Medan, Indonesia
}

\begin{abstract}
Anxiety is the signal and phenomenon of a threat that can be divided into mild, moderate, severe, and very severe anxiety based on its level. Anxiety can cause pathological changes in the body including the oral cavity. Burning mouth syndrome (BMS) is one of the disorders in oral cavity that can be affected by anxiety. BMS is an oral disorder that consists of a burning pain in the mouth without any visible clinical manifestations. The question about whether anxiety is cause or effect of BMS remain unanswered. The objective of this study was to analyze the relationship between anxiety and burning mouth syndrome. This was an observational analytic study with cross sectional approach. Subjects were 50 psychiatric outpatients with main symptom of anxiety in Pirngadi Hospital Medan selected with purposive sampling. Data was collected by anamnesis, clinical examination, and interview with Hamilton Rating Scale for Anxiety (HRS-A) questionnaire. This study showed that there are 6 patients (12\%) experiencing BMS. Fisher's exact test showed a significant result between anxiety level and BMS with $p=0.001 \quad(p<0.05)$. There was a significant correlation between anxiety level and BMS. Increased level of anxiety shows increasing number of BMS.
\end{abstract}

Keywords-anxiety, anxiety level, burning mouth syndrome

\section{INTRODUCTION}

Anxiety is a warning and signal of an internal or external threat [1,2]. Acute or chronic anxiety symptoms are a major component of almost all psychiatric disorders [3]. Psychiatric disorders such as anxiety and depression based on Indonesia Health Research Data showed a prevalence of 6\% in 2013 [4].

Anxiety can be divided by its level into mild, moderate, severe, and very severy [2]. Anxiety can cause pathological changes in the body including the oral cavity [5].Oral lichen planus (OLP), recurrent aphthous stomatitis (RAS), and burning mouth syndrome (BMS) can be affected by anxiety $[5,6]$.

Burning mouth syndrome (BMS) can be characterized by pain in the mouth, usually accompanied by a burning sensation in the tongue, lips, and oral mucosa without any visible clinical manifestation [7]. Etiology of BMS is still unclear and the etiological factors can be divided into local, systemic, and psychogenic [8]. Persistence of the symptoms can cause emotional alterations of the patient [9]. Treatment of BMS aim to relieve the etiological factors whic can aggrevate the symptoms [8].

There were still not many study on the relationship between anxiety and BMS. Study about relationship between anxiety based on its level with BMS has not been done. The aim of this study is to analyze the relationship between anxiety and BMS of psychiatric outpatients in Pirngadi Hospital Medan.

\section{MATERIALS AND METHODS}

This study was approved by the Health Research Ethical Committee, University of Sumatera Utara number 304, and all subjects provided informed consent. This was an observational analytic study with cross sectional approach. Fifty psychiatric outpatients with main symptom of anxiety in Pirngadi Hospital Medan were selected by purposive sampling.

The subject criteria was psychiatric outpatients with main symptom of anxiety based on medical records, patient who are not menopausal, absence of systemic disease such as diabetes mellitus, were not taking angiotensin converting enzyme inhibitors (ACE inhibitors) medications (e.g., captopril, enalapril, and lisinopril), absence of denture wearing, and willing to be the subject of the study.

Data were collected by the use of Hospital's medical record to determine anxiety as the main symptom of the patients. Anxiety level was obtain from Hamilton Rating Scale for Anxiety (HRS-A) questionnaire. Diagnosis of BMS was based on anamnesis for determine pain or oral burning. Clinical examination was done to see the abscence of any lession in oral mucosa.

Data was analyzed with Fisher's exact test. It was used to analyze the relationship between anxiety level and BMS. This study showed that there is a relationship between anxiety level and BMS.

\section{RESULTS}

Demographic data of this study showed that the subjects of this study mostly were male, with frequency $29(58 \%)$ and $21(42 \%)$. Based on the age group, subjects aged $\geq 45$ years were $21(42 \%), 35-44$ years 
were $15(30 \%), 25-34$ years were $12(24 \%)$, and 18-24 years were $2(4 \%)$. (Table I and Table II)

TABLE I. DISTRIBUTION AND FREQUENCY PATIENTS BASED ON GENDER

\begin{tabular}{|c|c|c|}
\hline Gender & $\mathbf{n}$ & \% \\
\hline Male & 29 & 58 \\
\hline Female & 21 & 42 \\
\hline Total & 50 & 100 \\
\hline
\end{tabular}

TABLE II. DISTRIBUTION AND FREQUENCY PATIENTS BASED ON AGE

\begin{tabular}{|c|c|c|}
\hline Age & n & \% \\
\hline $18-24$ years & 2 & 4 \\
\hline $25-34$ years & 12 & 24 \\
\hline $35-44$ years & 15 & 30 \\
\hline$\geq 45$ years & 21 & 42 \\
\hline Total & 50 & 100 \\
\hline
\end{tabular}

This study showed that subjects with mild anxiety were $39(78 \%)$ while the subjects with moderate anxiety were $11(22 \%)$. No subject with severe anxiety and very severe anxiety was found in this study. (Table III)

TABLE III. DISTRIBUTION AND FREQUENCY OF ANXIETY BASED ON ITS LEVEL

\begin{tabular}{|c|c|c|}
\hline Anxiety & n & \% \\
\hline Mild anxiety & 39 & 78 \\
\hline Moderate anxiety & 11 & 22 \\
\hline Severe anxiety & 0 & 0 \\
\hline Very severe anxiety & 0 & 0 \\
\hline Total & 50 & 100 \\
\hline
\end{tabular}

Distribution and frequency of burning mouth syndrome in psychiatric outpatients with main symptom of anxiety showed that from 50 subjects, 6 persons (12\%) had BMS while 44 others $(88 \%)$ did not have BMS. (Table IV)

TABLE IV. DISTRIBUTION AND FREQUENCY OF BURNING MOUTH SYNDROME

\begin{tabular}{|c|c|c|}
\hline BMS & n & \% \\
\hline BMS (+) & 6 & 12 \\
\hline BMS (-) & 44 & 88 \\
\hline Total & 50 & 100 \\
\hline
\end{tabular}

Table $\mathrm{V}$ confirmed that from 6 cases with BMS, 1 patient $(2 \%)$ had mild anxiety while 5 patients (10\%) were with moderate anxiety. No BMS data was found on severe anxiety and very severe anxiety.

TABLE V. DISTRIBUTION AND FREQUENCYOF BMS BASED ON ANXIEY LEVEL

\begin{tabular}{|c|c|c|}
\hline \multirow{2}{*}{ Anxiety } & \multicolumn{2}{|c|}{ BMS } \\
\cline { 2 - 3 } & $\mathbf{n}$ & $\mathbf{\%}$ \\
\hline Mild & 1 & 2 \\
\hline Moderate & 5 & 10 \\
\hline Severe & 0 & 0 \\
\hline Very severe & 0 & 0 \\
\hline Total & 6 & 12 \\
\hline
\end{tabular}

Relationship between anxiety level and BMS was calculated by Fisher's exact test with $\mathrm{p}<0.05$ ( $\mathrm{p}=0.001$ ). Therefore, this study showed that there is a significant correlation between anxiety level and BMS. (Table VI)
TABLE VI. RELATIONSHIP BETWEEN ANXIETY LEVEL AND BMS

\begin{tabular}{|c|c|c|c|c|c|}
\hline \multirow{2}{*}{ Anxiety } & \multicolumn{4}{|c|}{ BMS } & \multirow{2}{*}{ p } \\
\cline { 2 - 5 } & \multicolumn{2}{|c|}{ BMS (+) } & \multicolumn{2}{c|}{ BMS (-) } & \\
\cline { 2 - 5 } & $\mathrm{N}$ & $\%$ & $\mathrm{n}$ & $\%$ & \\
\hline Mild & 1 & 2 & 38 & 76 & \multirow{2}{*}{0.001} \\
\hline Moderate & 5 & 10 & 6 & 12 & \\
\hline Severe & 0 & 0 & 0 & 0 & \\
\hline Very severe & 0 & 0 & 0 & 0 & \\
\hline Total & 6 & 12 & 44 & 88 & \\
\hline
\end{tabular}

\section{DISCUSSION}

Anxiety are more common in female than in male by a ratio of 2:1 [10]. The National Comorbidity Study reported that anxiety occurs more often in female $(30.5 \%)$ compared to male (19.2\%) [1]. de Lijster et al. study also indicate that anxiety are more common in female compared to male with percentage, respectively, $70.55 \%$ and $29.45 \%$ [11]. In contrast, this study showed higher percentage of male $(58 \%)$. Difference in the result can be caused due to the methodology research differentiation. Female who have experienced menopausal was excluded as a subject in this study because menopausal is one of the factors in the occurrence of BMS.

Age range of anxiety are vary. In this study, the age group of $\geq 45$ years were higher than the other age groups with $21(42 \%)$ persons. World Health Organization (WHO) reported that anxiety in Brazil and Netherlands are also more common in $\geq 45$ years age group. ${ }^{12}$ Anxiety occurs if a person can not adapt to overcome with the causes of his/her anxiety such as social relations problems, occupation matter, poor environment, finances, menopause, or trauma. Anxiety can occur to anyone depending on their reaction or response to the cause of anxiety [3].

Anxiety level can be divided into mild, moderate, severe, and very severe [2]. The result of this study showed that mild anxiety are more experienced in the subjects (78\%). According to Mykletun et al. study in Norway from $15.5 \%$ persons that experienced anxiety; 9.9\% persons were mild anxiety, $4.6 \%$ were moderate, and $1 \%$ were severe [13]. Mild anxiety is a common anxiety that helps a person to solve problems, think, act, or protect themselves; such as helping student to focus in preparation for the exam [2]. Subjects in this study were psychiatric outpatients who had been treated and controlled periodically so that severe and very severe anxiety was not encountered.

The result of this study indicated that the distribution and frequency of BMS in psychiatric outpatients with main symptom of anxiety was $12 \%$. Suresh et al. study on patient with anxiety showed that prevalence of BMS were $2.87 \%$, whereas Aditya et al. reported that $9.5 \%$ patient with mental disorders including anxiety experiencing BMS [5.14]. There is a lack of strict adherence to diagnose BMS [15]. The differences in prevalence can occurs because of differentiation in BMS diagnostic criteria.

Study about BMS and anxiety is still rarely done and question about whether anxiety is cause or effect of BMS remains unanswered [15]. Buljan et al. 
investigated the relationship between anxiety, depression, BMS and showed from 120 subjects, as many as 42 subjects suffering from BMS with anxiety levels higher than other subjects [16]. Spanemberg et al. evaluated that $90 \%$ of BMS patient declared to feel anxiety symptoms such as nervous, tense, and worried [8].

This study showed that patients with moderate anxiety that experiencing BMS were more than patients with mild anxiety, with percentage, respectively, $10 \%$ and $2 \%$. The result of Suresh et al. study showed patients with severe anxiety who experienced BMS was $75 \%$, moderate anxiety was $25 \%$, and no patient with mild anxiety [5]. Anxiety can cause changes in the oral cavity [6]. Increased levels of anxiety can worsen body condition including oral cavity [2].

Buljan et al. showed that there was an association between anxiety and BMS with $\mathrm{p}<0.01$ and strong correlation between anxiety level and severity of BMS [12].In this study, relationship between anxiety level and BMS has a significant correlation $(\mathrm{p}=0.001)$. Anxiety would happen because of the response to the stressor; one of the example is occupation matter [12]. Anxiety as an emotional response will be forwarded to the center of emotional, which is called limbic system [3]. Hypothalamus is a part of limbic system that will release a hormone to stimulate pituitary gland in order to produce adrenocorticotropic hormone. Adrenocorticotropic hormone will stimulate adrenal cortex to release cortisol [17]. Anxiety is related to the increase of cortisol. Cortisol has a role in regeneration and protection of neural tissue. High levels of cortisol can damage the neural tissues and stimulates neuropathic changes which may evoke symptoms in BMS [18].

\section{ACKNOWLEDMENTS}

Many thanks to director of Pirngadi Hospital, dr. Mawar Tarigan, Sp.KJ, and all medical personnel in Pirngadi Hospital Medan especially the Psychiatric Clinic for their concern and assist in the implementation of this research.

\section{REFERENCES}

[1] B. J. Sadock, V. A. Sadock, and P. Ruiz, Synopsis of psychiatry. 11th ed. Philadelphia: Wolters Kluwer, 2015.

[2] S. L. Videbeck, Psychiatric - mental health nursing. 5th ed. Philadelphia: Wolters Kluwer, 2011.

[3] D. Hawari, Manajemen stres cemas dan depresi. Edisi 2. Jakarta: Badan Penerbit FKUI, 2016.

[4] Badan Peneliti dan Pengembangan Kesehatan, "Riset Kesehatan Dasar 2013," Riskesdas 2013. Kementrian Kesehatan RI., Jakarta., 2013.

[5] Suresh et al., "Psychosocial characteristics of oromucosal diseases in psychiatric patients: observational study from Indian dental college," North Am J Med Sci, vol. 6, pp. 570-574, November 2014.

[6] Suresh et al., "Oral mucosal diseases in anxiety and depression patients: hospital based observational study from south India," J Clin Exp Dent, vol. 7, no. 1, pp. e95-e99, August 2015.

[7] S. Vellappally, "Burning mouth syndrome: a review of the etiopathologic factors and management," The J of Cont Dent Pract 2016, vol. 17, no. 2, pp. 171-176, February 2016

[8] J. C. Spanemberg, A. R. Archilla, A. C. Salobrena, M. C. Coppola, and L. M. A. de Araujo, "Burning mouth syndrome: psychological aspects of Southern Brazil individuals," Revista Brasileira de Ciencias de Saude, vol. 9, no. 27, pp. 1-6, March 2011.

[9] J. S. Spanemberg, A. P. Dias, B. O. B. Barreriro, K. Cherubini, M. A. Z. de Figueiredo, and F. G. Salum, "Impact of burning mouth syndrome on quality of life," Rev Odonto Cienc, vol. 27, no. 3, pp. 191-195, August 2012.

[10] M. C. Townsend, Psychiatric mental health nursing. 6th ed. United States: FA Davis Company, 2009.

[11] J. M. de Lijster et al., "The age of onset of anxiety disorders: a meta-analysis," Can J Psychiatry, vol. 1, pp. 1-10, 2016.

[12] World Health Organization, "Cross-national comparisons ofthe prevalences and correlates of mental disorders: WHO international consortium in psychiatric epidemiology," Bull World Health Organ, vol. 78, no. 4, pp. 413-426, 2000.

[13] A. Mykletun, O. Bjerkeset, S. Overland, M. Prince, M. Dewey, and R. Stewart, "Levels of anxiety and depression as predictors of mortality: the HUNT study," Br J Psychiatry, vol. 195, pp. 118-125, February 2009.

[14] A. Aditya and S. Lele, "Prevalence of xerostomia and burning sensation in patients with psychosocial disorders," J Int Dent Med Res, vol. 4, no. 3, pp. 111-116, June 2011.

[15] F. Galli, G. Lodi, A. Sardella, and E. Vegni, "Role of psychological factors in burning mouth syndrome: A systematic review and meta- analysis," International Headache Society, vol. 1, pp. 1-13, March 2016.

[16] D. Buljan, I. Savic, D. Karlovic, "Correlation between anxiety, depression and burning mouth syndrome," Acta Clin Croat, vol. 47, pp. 211-216, November 2008.

[17] J. Nevid, S. Rathus, and B. Greene, Psikologi abnormal. Trans. Tim Fakultas Psikologi UI. Jakarta: Penerbit Erlangga, 2003.

[18] A. Woda, T. Dao, and C. Gremeau-Richard, "Steroid dysregulation and stomatodynia (burning mouth syndrome)," J Orofac Pain, vol. 23, no. 3, pp. 202-210, 2009. 